\title{
Does a Voluntary Job Change Affect Work-Family Balance?
}

\author{
Nina Tomaževič ${ }^{1}$, Tatjana Kozjek ${ }^{1}$ \& Janez Stare ${ }^{1}$ \\ ${ }^{1}$ Faculty of Administration, University of Ljubljana, Ljubljana, Slovenia \\ Correspondence: Nina Tomaževič, Faculty of Administration, University of Ljubljana, Gosarjeva ulica 5, 1000 \\ Ljubljana, Slovenia. Tel: 386-1-580-5400. E-mail: nina.tomazevic@ @u.uni-lj.si
}

Received: November 17, 2014

Accepted: December 1, 2014

Online Published: January 25, 2015

doi:10.5539/ibr.v8n2p1

URL: http://dx.doi.org/10.5539/ibr.v8n2p1

\begin{abstract}
The question of work-family balance (WFB) is an area where increasing attention is being paid nowadays since it relates to the health, satisfaction, personal development of employees, to the care for their children, youths and elder family members. The purpose of the paper is to explore the connection between the voluntary job change and the potential improvement of the work-family balance since it was assumed that changing the job voluntarily might bring to a higher WFB as employees could satisfy their needs more effectively in a new working environment, chosen by their own will. Data were collected using a combination of CAWI (computer assisted web interview) and pen and pencil methods. Employees from various companies and public sector organizations from Slovenia were invited to participate in the study. Hierarchical cluster analysis was performed to identify clusters of family-work balancers, i.e. of those, who help with balancing employees' work and family domains. Kruskal-Wallis test and Mann-Whitney U test were used to explore the correlation between the decision about the voluntary job change and the satisfaction with the work-family balance. The research has shown that the assessment of WFB does not depend on a voluntary job change. The exceptions are the group of employees with children (in a positive direction) and the group of employees without children and no help in the household (in a negative direction). The employees do not use a job change as a tool for increasing WFB. This is probably also due to the closed culture of Slovenians. The managers who do care about their employees and who do not wish to lose their best employees have therefore many possibilities to choose the proper coping strategies to help their employees balance their work and family lives.
\end{abstract}

Keywords: job change, turnover, work-family balance, employees, partners, parents

\section{Introduction}

Due to the changes in the society, balancing work and family lives in the last three decades became one of the most important issues to be solved on different levels since it relates to the health, satisfaction and personal development of employees, to the care for their children and youths, who cannot function solely by themselves and to the care for elder family members, who again become dependent on the nursing from others because of illness or oldness. The significance of work-family balance (WFB) came to the front mainly because of the increase on the number of women entering the paid labour force, ever more frequent employment of both partners, long working hours and stressful life both at work and with regard to balancing work and family life (Madsen, 2003; Desmarais \& Alksnis, 2005; Fleetwood, 2007).

A work-life issue, which is a wider concept than work-family issue, impacts everyone, regardless of education level, gender, income level, family structure, occupation, race, age, job status or religion (McMillan, Morris \& Atchley, 2011). Work-life balance is therefore a complex field, since it does not only relate to challenges faced by parents with children. Rather, it concerns everyone whose environment includes individuals in need of special care and assistance, including the sick and/or elderly. Ever more stressful circumstances at work demand also from those who do not have any obligations to their relatives at home, to care (at least) for their own balancing of work and private life. Everybody needs enough rest, relaxation and recreation in order to live a full life and to be efficient and effective at work and in life in general on a long run. Finding a balance between different areas of life requires a range of measures and good cooperation by both employees, organisations and trade unions, and the state and local communities (Doorne-Huiskes, Remery, \& Schippers, 2003; COFACE, 2008). All parties involved must be aware of the existence of the problem related to balancing work and private life, especially of work and family life, and of their responsibilities in addressing it. 
On the basis of that we were interested in the responsibility the employees have to efficiently and effectively balance their work and family obligations. The purpose of our study was to find out whether a voluntary job change is a way to 'escape' the unsatisfactory circumstances regarding combining the work and family issues and to improve work-family balance or not. First, we investigated whether a voluntary job change impacts the assessment of work-family balance. Second, we examined who helps employees balancing their work and family life, third, we were interested in whether the type of help impacts the work-family balance assessment and fourth, whether there are any differences in the work-family balance assessment by those who voluntarily changed their job, analysed by clusters.

An important aspect of the paper is also that it clearly separates the voluntary turnover from the involuntary turnover and thus remedies a potential confusion in studies that have investigated a turnover measure that did not distinguish between voluntary and involuntary turnover (Clausen \& Borg, 2010; Moen, Kelly, \& Hill, 2011).

The terms job change and turnover will be used alternately in the paper, depending on the context and the emphasis the authors will make at different points. The paper proceeds as follows. Literature review is divided into three main sections. First, the definition and some of previous studies of work-family balance will be described, the second sequence will deal with the topics on who helps employees balance their work-family issues and the third will be formed in order to connect the job change (voluntary turnover) with work-family balance. The research section describes the empirical setting and the analysed data and is followed by the discussion and conclusion.

\section{Literature Review}

\subsection{Work-Family Balance}

The paper will focus on a narrower scope of work-life balance (WLB), a work-family balance (WFB) only. The representative of traditional efforts to define WFB Frone (2003) contends that balance occurs when there is a 'lack of conflict or interference between the work and family role'. Opponents such as Grzywacz and Carlson (2007) define WFB as 'the accomplishment of role-related expectations that are negotiated and shared between an individual and his or her role-related partners in work and family domains'. Greenhaus, Collins and Shaw (2003) define WFB as 'the extent to which individuals are equally engaged in - and equally satisfied with - their work and family roles'. They claim that the definition is broad enough so that it includes both positive and negative balances. To this end, balance becomes a continuum with imbalance (in either role) anchoring one end and balancing (again in either role) the other end. Greenhaus and Allen (2011) state that WFB has to be defined from a custom-tailored perspective; i.e. as the extent to which effectiveness and satisfaction in work and family roles are compatible with an individual's life values at a given point in time.

Clark (2000) in her 'work-family border theory' explains how individuals balance work and home by reducing role conflict and crossing the borders between these life realms, e.g. receiving family-oriented phone calls at work or taking business calls at home. According to that theory (Clark, 2000; Desrochers \& Sargent, 2004), work-family balance is defined as 'satisfaction and good functioning at work and at home, with a minimum of role conflict'. Borders exist between the work and family domains and when these borders are permeable and flexible, individuals can integrate the two domains to achieve balance. Work-family conflict arises when individuals lack sufficient resources to devote to both domains.

Some researchers define work-family balance in terms of work-family conflict and facilitation, e.g. Grzywacz and Bass (2003), stating that work-family conflict maps onto the concept of demands, whereas capabilities are relevant for facilitation. Others have defined WFB as the absence of work-family conflict (Clark, 2001; Salzstein, Ting \& Salzstein, 2001). According to Goldsmith (2007) work-family imbalance (conflict) is bi-directional, which means that both affect each other indirectly through distress. Also work seems to have a disruptive effect on family life rather than the way round (Eby, Allen \& Brinley, 2005; Geurts, Taris, Kompier, Dikkers, van Hooff \& Kinnunen, 2005).

The Lattice Group (2010) claims that the current WL (and WF) models in the USA are organised around an ideal worker immune from family life and personal needs. But individuals with personal needs and a family often cannot perform as ideal workers. Achieving work-family balance is particularly difficult in the case of single-parent families and in the case of older children who are not yet able to look after themselves; therefore the formulation of a work-family balance policy should take into account all those who are not fully capable of looking after themselves (Švab, 2007; OECD, 2008).

Balancing work and family life is thus not only a matter of helping families or women, but a central social issue (Fernández Cordón, 2009). Parasuraman and Greenhaus (2002), Švab (2007) and Thévenon (2008) point out that 
when balancing family life and work it is also necessary to take into account the ageing population, meaning that in the future, support should not only be aimed at families with children but also at families caring for elderly relatives.

When an organization is considered as supportive to its employees' family lives (including work-family programs, work-family culture, management support), they tend to experience lower levels of work-family conflict and higher levels of job satisfaction (Lapierre et al., 2008; Fiksenbaum, 2013). Hill (2005) reports also that manager support of employee on the job itself had a stronger relationship to work-family conflict and work-family facilitation than manger support of the parent in family responsibilities.

Empirical studies have identified family-friendly policies and practices as antecedents of work-family balance (e.g., Anderson, Coffey \& Byerly, 2002; Premeaux, Adkins \& Mossholder, 2007). Workplace flexibility was discovered as an important antecedent of work-family balance (Swanberg, Werner, \& McKechnie, 2008). Similarly, our study focused on the impact of voluntary job change on the potential improvement of work-family balance.

Parasuraman and Greenhaus (2002) point out that the majority of studies on WFB are focused on employed men and women who are married or living with a partner or people with children. Single-earner mothers and fathers, single and childless employees with extensive obligations regarding eldercare, blended families with children from both partners' prior marriages, families with shared custody of children and grandparents raising their grandchildren have been omitted from studies. Our study included employees of different statuses (marital status: married, single; household type: living with partners and/or children, living with relatives).

\subsection{Who Helps Employees Balance Their Work and Family Issues}

Considerable changes in labour force demographics and family composition have taken place in the past few decades, making the challenge of adequately balancing work and family roles one of today's central concerns for individuals (Valcour, 2007). The problematic of WFB has to be resolved by all involved, i.e. state, local communities, trade unions, employers and employee themselves. Gonyea and Googins (1996) claim that the majority of research in this area has taken place in North America where there is little expectation of a role for the state. Lewis and Smithson (2001), for example, explored employees' expectations of support from the state and employers in five European countries. Our paper will only focus on the activities an employee himself/herself should undertake in order to balance his/her work and family life as effectively and efficiently as possible.

Many authors state that the key role of employees is to communicate their needs and wants regarding WFB to the employers, trade unions and state authorities. If the employees expect the help from the employers, they have to communicate and implement their initiatives in the following spheres (Trefalt \& Perlow, 2005; Peus, 2006; European Economic and Social Committee, 2007; Černigoj Sadar et al., 2007; Littig, 2008; EQUAL, 2009; Eurofound, 2009; Novozymes, 2010):

- The needs regarding the organization of nursing for pre-school children (nursing the pre-school kids);

- Wishes regarding shorter working-hours or more flexible schedule;

- (Co)deciding regarding the quantity and place of work;

- Pointing out about the discriminatory employment;

- Balancing three dimensions - employee's job requirements, his/her partner's job requirements and requirements that arise due to the family issues;

- The needs and wants regarding the help in the household;

- Cooperation in establishing the intergenerational network in an organization;

- Desires regarding socializing outside the working hours, e.g. Trips, picnics with family members, christmas presents for kids etc..;

- Active cooperation in the discussions with employers regarding the termination of maternity leave and returning to work;

- Retaining and upgrading the knowledge while absent;

- Looking for help from employee representatives, internal or external consultants (social workers, lawyers);

- Care for healthy nutrition, relaxation, recreation - both at work and in the spare time;

- Care for personal development and training in the fields that support wfb, e.g. Stress reduction, time management etc.. 
The employers should seriously and individually consider the needs and desires of employees and take into account that the needs and desires of an individual employee change over time as the children grow up, e.g. they need parents in the primary and in the secondary school in a different sense compared to the pre-school period. Besides that some employees have and others do not have nearby the relatives and/or friends (or financial sources to hire the services of nurses/baby-sitters) who can help them balancing their work and family issues. The differences in the way how do the individuals balance their work and family show up also because of the differences in their personalities, since the employees use to solve similar problems in quite different ways.

The measures that were stated two paragraphs above are the ones the employee can execute mainly at work. But at home the employees either decide or are compelled to do everything by himself/herself and some of them have the possibility to ask their relatives, neighbours, friends or different kinds of institutions to help them balance their work and family realms. Most commonly the helpers are (Stewart, 1993; Voydanoff, 2001; Hyman, Scholarios, \& Baldry, 2005): partner, parents, grandparents, other family members (employee's siblings, aunts, etc.), neighbours and institutional caregivers.

Stewart (1993) defined social support as 'interactions with family member, friends, peers, and health care providers that communicate information, esteem, aid, and reliable alliance which improve coping, moderate the impact of stressors and promote health'. Mudry, Kushner and Neufeld (2010) distinguished five types of support sources: household family, nonhousehold family, friends and neighbours, workplace and formal services. The employees' use of social support is influenced by the various perceptions about their identity, roles, the expectations for themselves as workers, and responsibilities, and how they situate themselves in society. Some might also experience barriers in accessing social support, including the perception that they are a burden to others, lack of reciprocity, reluctance to ask for support, and negative interactions accompanying supportive actions (Harrison, Neufeld, \& Kushner, 1995). Social support is recognized as an important factor in maintaining health, coping with illness and preventing disease (Stewart, 1993).

In case the employees will feel they cannot fulfil their needs and wants regarding balancing work and family realms, they will look for various solutions. Some of the most frequent measures the individuals take in order to try to balance their work and family lives are (Firth, Mellor, Moore \& Loquet, 2004; Park \& Kim, 2009):

- Resolving the conflicts with the superior;

- Resolving the conflicts with family members;

- More frequent leave due to the illness of a family member;

- Presenteism;

- More frequent leave due to the illness of an employee himself/herself;

- More frequent leave in order to arrange private issues;

- Sports/relaxation;

- Change of an employer;

- Exit from a labour market in order to stay with a family.

The job change or quitting with any employment for part time or forever are among the solutions the employees use for balancing their work and family lives more effectively and efficiently.

\subsection{Job Change (As a Voluntary Turnover) and Work-Family Balance}

A very broad definition of employee turnover was designed by Abassi and Hollman (2000) and means the rotation of workers around the labour market - between organizations, jobs and occupations; and between states of employment and unemployment. According to Woods (1995) turnover is the entire process associated with filling a vacancy: each time a position is vacated, either voluntarily or involuntarily, a new employee must be hired and trained.

Voluntary turnover is employee's voluntary withdrawal from the organization (de Croon, Sluiter, Blonk, Broersen, \& Frings-Dresen, 2004). In case the organizations have invested a lot in training, developing and retaining their employees, a turnover of skilled and professional staff can incur substantial costs for organizations since recruiting and training new employees are very costly (Gustafson, 2002; Doorewaard, \& Benschop, 2003; Somaya \& Williamson, 2008). Johnson, Griffeth, and Griffin (2002) estimate that hiring and training a replacement worker for a lost employee costs approximately 50 percent of the worker's annual salary. High staff turnover can also influence negatively the quality of services and products and, consequentially, the customer satisfaction (Gray \& Phillips, 1996; Ongori, 2007). According to Armstrong (2009) and Dess and Shaw (2001) voluntary turnover 
incurs significant cost, both in terms of direct costs (failure to use expertise and experience gained by a leaving employee, replacement, recruitment and selection, temporary staff, management time, the possible loss of customers) and also (and perhaps more significantly) in terms of indirect costs (lower morale, pressure on remaining staff, cost of learning, product/service quality, organizational memory) and the loss of social capital. Hinkin and Tracey (2010) connect work-family issues with employee behaviours (notably, voluntary turnover) that are known to directly affect the performance and profitability of organizations.

People change their jobs and careers for different reasons, e.g. in order to gain a broader base of knowledge, to increase their earning power, to find more challenging work, to change the (toxic) social environment (co-workers, bosses), to run away before the company closes down due to a bad performance, to avoid poor human resource management practices, to catch a better offer, to reduce job stress, dissatisfaction and/or burnout etc. (Idson \& Feaster, 1990; Guinmaraes, 1997; Maslach, Schaufeli, \& Leiter, 2001, Abassi \& Hollman, 2000; Firth et al., 2004; Mano-Negrin \& Tzafrir, 2004; Schermerhorn, Hunt, \& Osborn, 2005; Park \& Kim, 2009; Cohen \& Golan, 2007, Cunningham, 2013).

One of the important reasons for turnover are also changes in employees' private life, such as marrying with somebody from another town/country, getting a baby, having aging parents, etc. In case the employee communicates these changes to the employer, it can be of benefit for both to adapt employee's job requirements or help him/her find a new job within the company that better meets her/his life needs. If that isn't possible, the employer may become a powerful reference as the employee searches for a new job. In some cases, the employer might even be willing to help the employee find a new job, cultivating a long-term relationship in case employee is able to return in the future (Deepa \& Steela, 2012; Cunningham, 2013).

In the past, the need to provide care for children and aged relatives has been classified as involuntary turnover. Today such factors should not be seen as involuntary turnover as both government regulation and company policies create the chance for such staff to come back to work, or to continue to work on a more flexible basis (Booth \& Hamer, 2007).

The results of the research on the voluntary turnover (job change) and work-life balance are available mainly in the direction of investigating the WFB situation and its effect on turnover intention and turnover itself (e.g., Forsyth \& Polzer-Debruyne, 2007). Mosadeghrad (2013) examined quality of working life (a dimension of which is also work-life balance) as an antecedent of employee turnover intention. Turnover intention may therefore be an indicator of low quality of working life. According to Vanderpool and Way (2013), work-family balance affects organizationally relevant employee psychological outcomes (i.e., job anxiety and turnover intentions) and is a predictor of voluntary turnover. Therefore the managers should help employees maintain their work and family balance and correct imbalances. Bloome, Van Rhede and Tromp (2010) found out that work-family conflict and organizational support can explain a substantial amount of variance among highly educated employees regarding their intention to leave an organization.

Ton and Huckman (2008) claim that majority of attention regarding the employee turnover in organizations has been focused on understanding its causes and less on its consequences, either negative or positive. The examples of the later are that new employees bring in new ideas, attitudes and keep the organization fresh and current, a more suitable employee can be hired, the organization can improve the process of HR planning as well as development and succession management (Zografos, 2006; Somaya \& Williamson, 2008; Armstrong, 2009). However, the research on the consequences of turnover covers mainly the consequences for employers, not for employees as it was investigated in our study.

We assumed that changing the job voluntarily might bring to a higher work-family balance as employees could satisfy his/her needs more effectively in a new working environment with improved conditions for WFB (e.g. more flexible working hours, location closer to home and/or kindergarten/school, family-friendly organization etc.). Having that in mind we conducted a study based on four hypotheses, as follows. H1: Respondents who voluntarily changed their job in the past assess their work-family balance as higher than those who did not change a job.

The hypothesis was formed on the basis of the assumption that the employees who had in the past a possibility to change the job voluntarily, changed it (also) in a way that it helped them balance their work-family issues more effectively and efficiently. Therefore they should have higher WFB than those who have not changed their job (voluntarily) in the past.

An emerging body of literature indicates that the employees use different coping strategies to manage the imbalance between work and family domains (Bakker \& Demerouti, 2007; Astvik \& Melin, 2012) and that there are many groups of people around the employees who help them balancing their work and family domains 
(Voydanoff, 2001; Hyman, Scholarios \& Baldry, 2005). The second hypothesis was therefore H2: Respondents can be clustered in various groups according to who is helping them in balancing their work and family life.

Combining the logic of the first and second hypothesis we formed also the third and the forth one - H3: Clusters of work-family balancers differ in work-family balance assessment and H4: Respondents who voluntarily changed their job in the past have higher work-family balance inside each work-family balancers' cluster.

\section{Research}

Data were collected using a combination of CAWI (computer assisted web interview) and pen and pencil methods. Employees from various companies and public sector were invited to participate in the study. The criterion for selecting participants was their working status (they had to be employed) and their age (at least 18 yrs old). The data were collected in two ways:

- T.I.M. institute randomly selected people included in their panel that met inclusion criteria and invited them to participate in the study $(\mathrm{n}=577$ responded to the invitation);

- Students of Faculty of Administration from University of Ljubljana were asked to give questionnaires to their relatives or friends that met the inclusion criteria ( $n=365$ questionnaires were returned in this way).

Data collection was carried out from March to April 2012. Final sample consisted of $n=942$ respondents with the following demographic characteristics:

- $63 \%$ female and $37 \%$ male;

- Mean age (median, standard deviation): 38.7 yrs $(38,10.5)$;

- $2 \%$ of the sample completed compulsory education or less, $43 \%$ completed high school or vocational school and $55 \%$ completed higher education;

- Region of employment: $48 \%$ of the respondents were employed in the central Slovenian region, $13 \%$ in the Gorenjska region, $8 \%$ in the Pomurje region and $7 \%$ in the Podravje region;

- Mean overall period of employment (years of service) (median, standard deviation) was $16.1 \mathrm{yrs}(14,11.7)$.

The first hypothesis (H1) was tested treating the job change as independent variable measured by the question: "Have you ever changed your job voluntarily?" with possible reply "Yes" or "No". Dependent variable, work-family balance, was measured by the question: "In general, how would you assess your work-family balance?" on the 5-point scale (1 - very low, 5 - excellent). As distribution of the dependent variable significantly deviates from the normal (Shapiro-Wilk statistics $=0.88 ; \mathrm{p}=0.000$ ) the hypothesis was tested using Mann-Whitney U test.

Hierarchical cluster analysis using Ward method (and Euclidean distance as similarity measure) was performed to identify clusters of work-family balancers. Clusters of respondents were identified by similarity of their answer to the question: "Who in your household helps you balancing work and family life?" The possible responses were:

- Partner;

- Children;

- Yours or partner's parents;

- Yours or partner's grandparents;

- Other family members;

- Kindergarten;

- Baby sitter;

- Retirement home;

- Voluntary caregivers;

- I do everything by myself.

And were each rated on 5-point frequency scale (1 - never; 5 - always). Only variables with the least missing values were used in the cluster analysis: partner, children, yours or your partner's parents, other family members and retirement home. Overall, $n=617$ respondents were classified in one of the identified clusters. Number of clusters was determined by dendrogram exploration (Appendix).

Kruskal - Wallis test was used to test the hypothesis H3. This test is the alternative to ANOVA when 
assumptions regarding normality and/or equality of variance-covariance matrix across groups are not met. Cluster membership was treated as an independent variable and work-family balance assessment as a dependent variable.

The Hypothesis H4 was tested using Mann-Whitney U test. Job change was treated as an independent variable and the assessment of work-family balance as a dependent variable. Hypotheses were tested at $\alpha=0.05$ level of significance (two-tailed).

\section{Results}

$10 \%$ of respondents who voluntarily changed their job in the past assessed their work-family balance as very poor (assessments 1 and 2) and 58\% as very good (assessments 4 and 5) (Table 1). The proportions of respondents with no job change were $9 \%$ and $57 \%$, respectively. Mean and median value of work-family balance assessment is similar for both groups. Mann-Whitney U test showed no significant difference in work-family balance assessment between respondents with and without job change behaviour in the past (Mann-Whitney $\mathrm{U}=$ 72925.5; $\mathrm{p}=0.955)$.

Table 1. Assessment of work-family balance with regard to voluntary job change

\begin{tabular}{llccccccccc}
\hline Work-family balance & & Very Low & 2 & 3 & 4 & Excellent & Mean & Median & Std. dev. & $\mathrm{n}$ \\
\hline & Job change - NO & $2 \%$ & $7 \%$ & $35 \%$ & $43 \%$ & $14 \%$ & 3.6 & 4.0 & 0.86 & 394 \\
& Job change - YES & $1 \%$ & $9 \%$ & $33 \%$ & $42 \%$ & $16 \%$ & 3.6 & 4.0 & 0.89 & 371 \\
\hline
\end{tabular}

The cluster analysis identified four clusters of work-family balancers. Overall, $\mathrm{n}=617$ respondents were classified in one of the clusters. Some descriptive statistics of the four clusters are shown in Figure 1 and Figure 2. Clusters are named after members that cooperate in balancing work and family life. Chi squared test analysis showed that clusters differ in the following demographic characteristics:

- $\quad$ Age $\left(\chi^{2}=53.78 ; \mathrm{p}=0.000\right)$;

- Marital status $(\chi 2=537.14 ; \mathrm{p}=0.000)$;

- Children in the household $\left(\chi^{2}=196.75 ; \mathrm{p}=0.000\right)$.

Borderline differences among clusters are also noted regarding education $\left(\chi^{2}=7.78 ; \mathrm{p}=0.051\right)$ and region of residence $\left(\chi^{2}=7.63 ; \mathrm{p}=0.051\right)$.

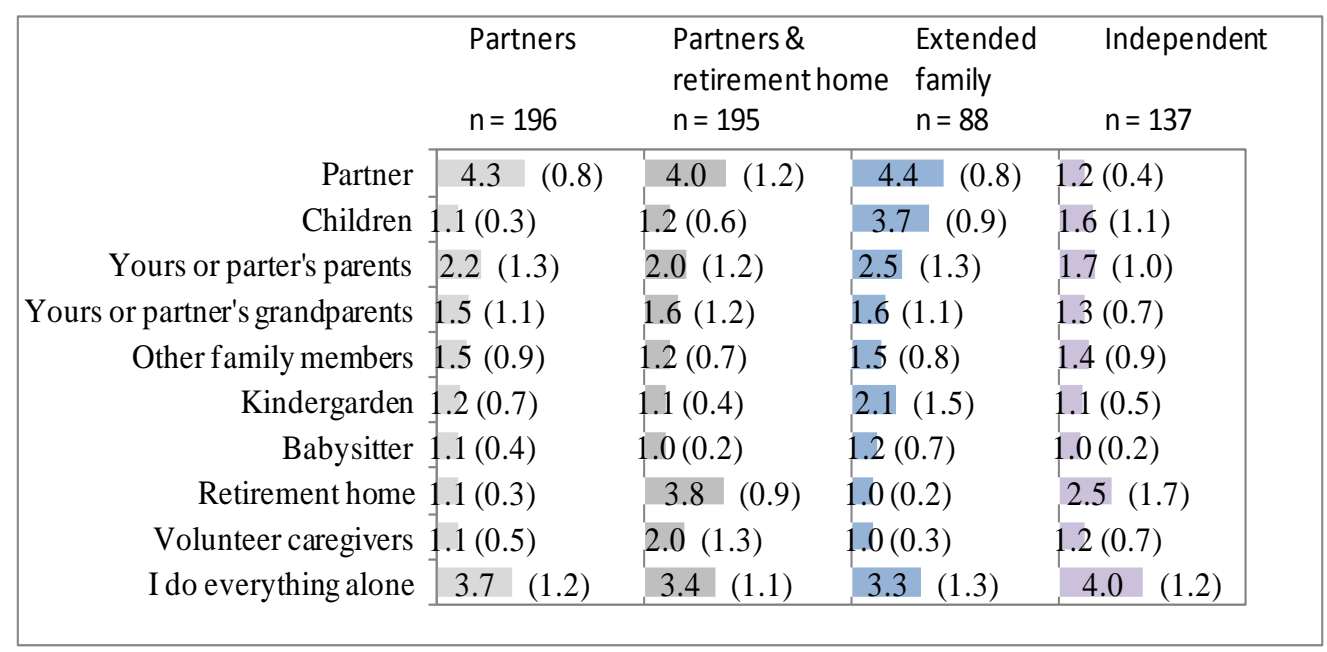

Figure 1. Cluster description: size of clusters, mean (standard deviation) importance (expressed in frequency) of each member's help (missing values not included) 


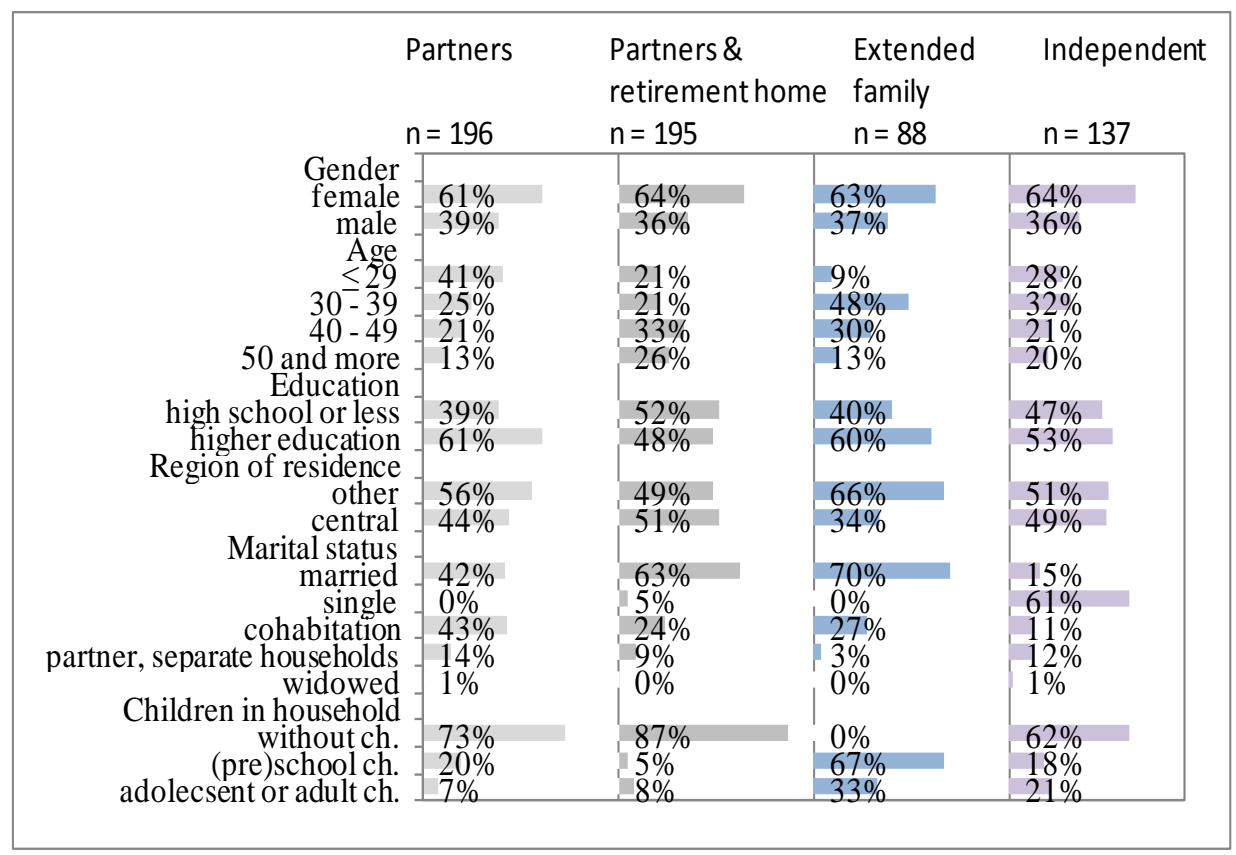

Figure 2. Demographic data by clusters (missing values not included)

The first cluster is named "partners" because in this cluster it is mainly the respondent and his/her partner that help each other balance employee's work and family domains. The size of this cluster is $32 \%(\mathrm{n}=196)$ and consists primarily of younger people with higher education who live together $(85 \%)$ but in general do not yet have children $(73 \%)$.

The second cluster is named "partners \& retirement home" as retirement home also helps partners with work-family balancing. The size of the cluster is $32 \%(\mathrm{n}=195)$ with $59 \%$ of respondents in this cluster being at least 40 years old and $52 \%$ having lower education (high school, vocational school or less). Majority is sharing a household with a partner or husband (87\%) and have adult children that live elsewhere or do not have children at all $(87 \%)$.

The third cluster is "extended family" cluster, as other family members, children, and grandparents are also helping in balancing work and family lives of respondents. This is a relatively small cluster comprising only $14 \%$ $(\mathrm{n}=88)$ respondents. Almost half of the cluster members are between 30 and 39 years old, mostly married $(70 \%)$ and having higher education (60\%). In comparison to other clusters, the largest proportion of respondents in this cluster lives in regions other than the central Slovenian region. All cluster members have children, mostly (67\%) preschool or elementary school, living in the household.

The fourth cluster is named an "independent" cluster, because the respondents in this cluster are balancing their work-family life by themselves. $22 \%(\mathrm{n}=138)$ of respondents belong to this cluster. The majority of them are single $(61 \%)$ and do not have children living in their household $(62 \%)$.

The next step in the analysis was assessing how the respondents, belonging to each of the identified clusters, assessed their work-family balance. Centrality and dispersion measures are given in Table 2.

Table 2. Work-family balance assessment by clusters

\begin{tabular}{lcccc}
\hline Clusters & Mean & Median & Standard Deviation & $\mathrm{n}$ \\
\hline Partners & 3.64 & 4 & 0.91 & 196 \\
Partners \& retirement home & 3.74 & 4 & 0.79 & 195 \\
Extended family & 3.42 & 3 & 0.92 & 88 \\
\hline
\end{tabular}

The lowest assessment of work-family balance was given by the "extended family" cluster and the highest by "partners and retirement home" cluster. There is a trend toward lower work-family balance among respondents 
who have preschool children or elementary school children in their household. In contrast, respondents above 40 years and with no children in the household and with retirement home also helping them balance their work and family life tend to have higher work-family balance.

The final step of the analysis was to assess whether the correlation between a job change and work-family balance assessment is present in each of the clusters. Figure 3 shows a mean (median; standard deviation) of work-family balance ratings for respondents who did and who did not voluntarily change their job in the past by clusters.

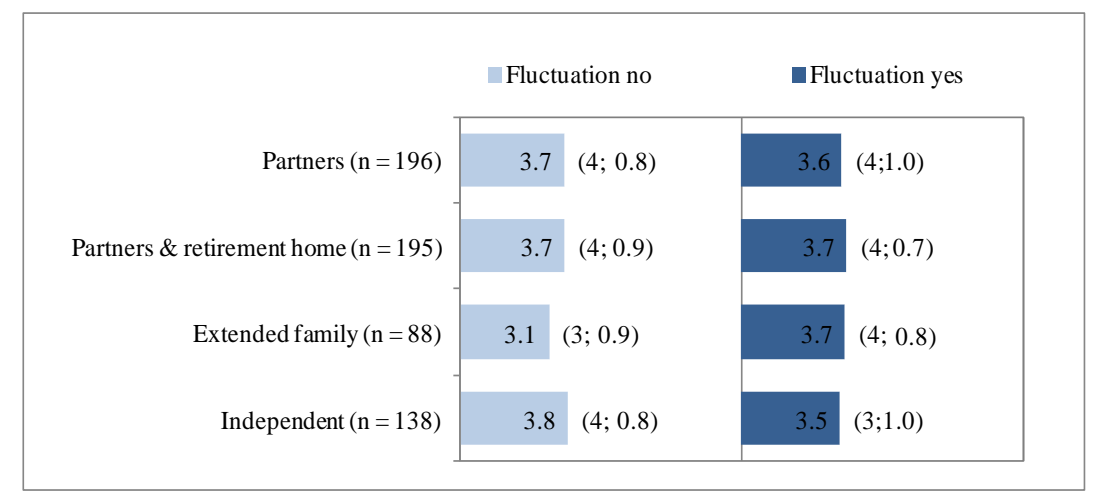

Figure 3. Job change by clusters; mean (median; standard deviation)

Respondents belonging to the "partners" cluster gave a similar work-family balance assessment irrespective of their voluntary employment change status in the past (Mann-Whitney $U=4270 ; p=0.656$ ). The same holds true for the "partners and retirement home" cluster (Mann-Whitney $U=4474 ; \mathrm{p}=0.986$ ).

Respondents belonging to the "extended family" cluster who have changed their employment in the past show higher work-family balance than those who have not (Mann-Whitney $U=606 ; p=0.009$ ). It seems that for those members of these clusters who voluntarily changed their employment, the change improved their work-family balance. It can be assumed that after having children some respondents searched for employment that would help them balance between work and family realms more effectively and also succeeded in this search.

Mean values for "independent" cluster show an entirely different picture which leads to the exactly opposite conclusion. Work-family balance is lower among respondents who have voluntarily changed their employment in the past (Mann-Whitney $U=1639.5 ; \mathrm{p}=0.019$ ). The majority of the respondents in this cluster are single and without children. It can be assumed that in their work plays a very important or even the most important role in their life, i.e. that they value the work more than other values (e.g. family, free time, health, etc.). If they changed employment to promote their career, they were probably prepared to put more effort and their time to succeed at work and therefore they dedicated less time to their family or hobbies.

\section{Discussion}

The central question for this article has concerned the impact of a voluntary job change on the potential improvement of work-family balance since a job change is recognized as one of the coping strategies for work-family balance improvement (Firth, Mellor, Moore, \& Loquet, 2004; Bakker \& Demerouti, 2007; Park \& Kim, 2009; Astvik \& Melin, 2012). It was initially established that the results of the analysis do not support the hypothesis H1, i.e. that the work-family balance assessment seems to be independent from a voluntary job change. The results are consistent with the theory and could be interpreted in a way that those who assessed WFB as lower, changed their job and others did not, so that therefore in the moment of the measurement there was no difference in the WFB assessment of both groups of respondents. Since there was no information on the assessment of the WFB before changing the job, these could, of course, be only the assumptions.

The second hypotheses was in line with the existing theory (Stewart, 1993; Voydanoff, 2001; Hyman, Scholarios \& Baldry, 2005; Mudry, Kushner \& Neufeld, 2010) and was set in order to find out whether there can be any clusters formed regarding those who help the employees balance their work and family lives. Due to the fact that it was possible to classify respondents in a manageable number of clusters regarding individuals/institutions helping them to balance their work-family life, the hypothesis $\mathrm{H} 2$ can be fully supported.

However, our findings did not reveal any differences between the clusters of work-family balancers regarding the work-family balance assessment. Kruskal-Wallis test showed no significant differences among the clusters 
$\left(\chi^{2}=6.74 ; p=0.081\right)$. Results thus do not support the hypothesis $\mathrm{H} 3$ and can be understood in the way that within each cluster the respondents (regardless of who helps them) try to optimize the WFB in their best possible way.

Within the fourth hypotheses it was assumed that the respondents who voluntarily changed their job in the past have higher work-family balance inside each work-family balancers' cluster. The results have shown that the hypothesis $\mathrm{H} 4$ can only be supported for the "extended family" cluster. This could be interpreted in the way that some of the respondents in the "extended family" cluster didn't want to take a risk of changing a job due to the responsibility towards their children which manifests also the statistical difference between them and others who dared to make a change. Regarding the respondents in the "independent" cluster the results show that the single employees assess the WFB after voluntarily changing the job as lower since they did it out of other motives and were prepared to speed up their career irrespective of the consequences for their work and family/private life balance.

\section{Conclusion}

The answer to the question in the title of the article is therefore clear. It is a 'NO' for the assessment of WFB from all respondents together but when analysing the results by clusters of those who differ regarding the type of help they use for balancing their work and family lives more efficiently, the results revealed that the employees with children are less prepared to take a risk of changing a job and are therefore prepared to stay in the environment that they assess as the one who offers them less possibilities for WFB. On the other hand single employees are prepared to change a job even if it means a worsening of WFB possibilities since they put other issues in the career in the forefront of their values.

Employees function in different working environments and have, due to the different experience and different personal needs, different expectations connected with balancing their work and family life. Our study that was conducted among employees in the framework of the project 'Improvement of working environment with innovative solutions' revealed, that the majority of respondents assess that they manage to balance their work and family domains quite effectively and with very little differences regarding the type of help they use when balancing their work and family lives. Therefore it could be concluded that the employees do not understand and/or use a job change as a tool for increasing WFB. This is probably also due to the closed culture of Slovenian citizens who are not keen on making big changes in their lives, changing jobs or even places to live in case the job change requires it.

The Slovenian managers who do care about their employees and who do not wish to lose their best employees have therefore many possibilities to choose the proper coping strategies to help their employees balance their work and family lives. It is also the economic situation that makes employees less prepared to take a risk of changing the job and therefore it is of the interest not only of employees and employers, but also of the state that they all look for the proactive and preventive rather than reactive measures for effective and efficient balancing of work and family lives.

The avenues for further research lie in the comparison of the WFB situation before and after the job change, in the analysis of the results by the branches, in international comparison and in conducting the interviews with employers and employees to verify situation with the subjective points of view and to get insight into the personal and more individual issues connected with balancing work and family lives.

\section{References}

Abassi, S. M., \& Hollman, K. W. (2000). Turnover: the real bottom line. Public Personnel Management, 2, $333-$ 342 .

Armstrong, M. (2009). Handbook of Human Resource Management Practice. London: Kogan Page.

Astvik, W., \& Melin, M. (2012). Coping with the imbalance between job demands and resources: A study of different coping patterns and implications for health and quality in human service work. Journal of Social Work, 1-24.

Bakker, A. B., \& Demerouti, E. (2007). The job demands-resources model: State of the art. Journal of Managerial Psychology, 22, 309-328. http://dx.doi.org/10.1108/02683940710733115

Bloome, R. J., Van Rhede, A., \& Tromp, D. M. (2010). Work-family conflict as a cause for turnover intentions in the hospitality industry. Tourism and Hospitality Research, 10, 269-285. http://dx.doi.org/10.1057/thr.2010.15

Booth, S., \& Hamer, K. (2007). Labour turnover in the retail industry: Predicting the role of individual, 
organisational and environmental factors. International Journal of Retail \& Distribution Management, 35, 289-307. http://dx.doi.org/10.1108/09590550710736210

Clark, S. C. (2000). Work/family border theory: A new theory of work/family balance. Human Relations, 53, 747-817. http://dx.doi.org/10.1177/0018726700536001

Clark, S. C. (2001). Work cultures and work/family balance. Journal of Vocational Behavior, 58, 348-365. http://dx.doi.org/10.1006/jvbe.2000.1759

Clausen, T., \& Borg, V. (2010). Do positive work-related states mediate the association between psychosocial work characteristics and turnover? A longitudinal analysis. International Journal of Stress Management, 17, 308-332. http://dx.doi.org/10.1037/a0021069

COFACE (Confederation of Family Organizations in the European Union). (2008). COFACE Position on reconciling family life, private life and professional life to prevent poverty and social exclusion. Retrieved $\begin{array}{llll}\text { October 25, 2013, from } & \text { 25, }\end{array}$ http://coface-eu.org/en/upload/WG\%20SOCIAL/WG1-2008-PositionCOFACE-reconciliation-EN.pdf

Cohen, A., \& Golan, R. (2007). Predicting absenteeism and turnover intentions by past absenteeism and work attitudes: An empirical examination of female employees in long term nursing care facilities. Career Development International, 12, 416-432. http://dx.doi.org/10.1108/13620430710773745

De Croon, E. M., Sluiter, J. K., Blonk, R. W., Broersen, J. P., \& Frings-Dresen, M. H. (2004). Stressful Work, Psychological Job Strain, and Turnover: A 2-Year Prospective Cohort Study of Truck Drivers. Journal of Applied Psychology, 89, 442-496. http://dx.doi.org/10.1037/0021-9010.89.3.442

Cunningham, M. (2013). 10 Reasons to Change Jobs. Retrieved May 15, 2014 from http://money.howstuffworks.com/second-career-ideas/10-reasons-to-change-jobs.htm\#page=0

Černigoj, S. N., Kanjuo, M. A., Stropnik, N., \& Žaucer, Š. B. (2007). Delo in družina - s partnerstvom do družini prijaznega delovnega okolja. (Work and family - with partnership to the family-friendly working environment). Ljubljana: Fakulteta za družbene vede.

Deepa, E., \& Steela, M. (2012). Employee turnover in 'IT' industry with special reference to Chennai City - an exploratory study. Zenith International Journal of Multidisciplinary Research, 2, 160-177.

Desrochers, S., \& Sargent, L. D. (2004). Boundary/border theory and work-family integration. Organization Management Journal, 1, 40-48. http://dx.doi.org/10.1057/omj.2004.11

Desmarais, S., \& Alksnis, C. (2005). Gender Issues. In J. Barling, M. Frone, \& E. K. Kelloway (Eds.), Handbook of Work Stress. Thousand Oaks, CA: Sage.

Doorewaard, H., \& Benschop, Y. (2003). HRM and organizational change: an emotional endeavour. Journal of Organizational Change Management, 16, 272-286. http://dx.doi.org/10.1108/09534810310475523

Doorne-Huiskes, A., Remery, C., \& Schippers, J. (2003). Family-friendly policies in the Netherlands. Utrecht: Utrecht University.

Eby, L. T., Allen, T. D., \& Brinley, A. (2005). A cross-level investigation of the relationship between career management practices and career-related attitudes. Group and Organization Management, 30, 565-596. http://dx.doi.org/10.1177/1059601104269118

Eurofound. (2009). Henkel, Germany: Increasing the labour market participation of underrepresented groups -

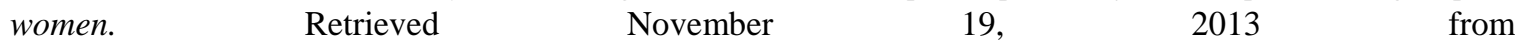
http://www.eurofound.europa.eu/areas/qualityofwork/betterjobs/cases/de02henkel.htm

European Economic and Social Committee. (2007). Mnenje Evropskega ekonomsko socialnega odbora o vlogi socialnih partnerjev pri usklajevanju poklicnega, družinskega in zasebnega življenja. The opinion of EESC on the role of social partners about balancing work, family and private life. Retrieved November 20, 2013 from http://www.socialnidialog.si/UserFiles/File/Soc\%20272\%20Fleksivarnost\%20(kolektivna\%20pogajanja\%2 0in\%20vloga\%20socialnega\%20dialoga).doc

EQUAL. (2009). Razvojno partnerstvo mladim materam/družinam prijazno zaposlovanje. Družini prijazno podjetje. Družinsko in poklicno življenje z roko v roki. Development partnership Young mothers/families friendly employments. Retrieved January, $16, \quad 2014 \quad$ from http://www.certifikatdpp.si/equal/images/teksti/Zlo_enka_Delodajalci.pdf 
Fernández Cordón, J. A. (2009). Policy issues for reconciling work and the family. The Unated Nations Expert Group Meeting on 'Family policy in a changing world: Promoting social protection intergenerational solidarity', Doha, Quatar, April 2009.

Fiksenbaum, L. M. (2013). Supportive work-family environments: implications for work-family conflict and well-being. The International Journal of Human Resource Management, 1-20.

Firth, L., Mellor, D. J., Moore, K. A., \& Loquet, C. (2004). How can managers reduce employee intention to quit? Journal of Managerial Psychology, 19, 170-187. http://dx.doi.org/10.1108/02683940410526127

Fleetwood, S. (2007). Why work-life balance now? The International Journal of Human Resource Management, 18, 387-400. http://dx.doi.org/10.1080/09585190601167441

Forsyth, S., \& Polzer-Debruyne, A. (2007). The organisational pay-offs for perceived work-life balance support. Asia Pacific Journal of Human Resources, 45, 113-123. http://dx.doi.org/10.1177/1038411107073610

Frone, M. R. (2003). Work-family balance. In J. C. Quick, \& L. E. Tetrick (Eds.), Handbook of occupational health psychology (2nd ed., pp. 143-162). Washington, DC: American Psychological Association. http://dx.doi.org/10.1037/10474-007

Geurts, S. A. E., Taris, T. W., Kompier, A. J., Dikkers, J. S. E., Van Hooff, L. M., \& Kinnunen, U. M. (2005). Work-home interaction from a workpsychological perspective: Development and validation of a new questionnaire, the SWING. Work \& Stress, 19, 319-339. http://dx.doi.org/10.1080/02678370500410208

Goldsmith, E. (2007). Stress, fatigue, and social support in the work and family context. Journal of Loss and Trauma, 12, 155-169. http://dx.doi.org/10.1080/15434610600854228

Gonyea, J., \& Googins, B. (1996). The restructuring of work and family in the US: A new challenge for American corporations (pp. 63-78). In S. Lewis, \& J. Lewis (Eds.), The work/family challenge: Rethinking employment. London: Sage.

Gray, A. M., \& Phillips, V. L. (1996). Labour turnover in the British National Health Service: a local labour market analysis. Health Policy, 36, 273-362. http://dx.doi.org/10.1016/0168-8510(96)00818-4

Greenhaus, J. H., \& Allen, T. D. (2011). Work-family balance: A review and extension of the literature. In J. C. Quick, \& L. E. Tetrick (Eds.), Handbook of occupational health psychology. Washington, DC: American Psychological Association.

Greenhaus, J. H., Collins, K. M., \& Shaw, J. D. (2003). The relation between work-family balance and quality of life. Journal of Vocational Behavior, 63, 510-531. http://dx.doi.org/10.1016/S0001-8791(02)00042-8

Grzywacz, J. G., \& Bass, B. L. (2003). Work, family and mental health: Testing different models of work-family fit. Journal of Marriage and Family, 65, 248-262. http://dx.doi.org/10.1111/j.1741-3737.2003.00248.x

Grzywacz, J. G., \& Carlson, D. S. (2007). Conceptualizing work-family balance: Implications for practice and research. Advances in Developing Human Resources, 9, 455-471. http://dx.doi.org/10.1177/1523422307305487

Guimaraes, T. (1997). Assessing Employee Turnover Intentions Before/After TQM. International Journal of Quality and Reliability Management, 14, 46-63. http://dx.doi.org/10.1108/02656719710156770

Gustafson, C. M. (2002). Employee turnover: a study of private clubs in the USA. International Journal of Contemporary Hospitality Management, 14, 106-113. http://dx.doi.org/10.1108/09596110210424385

Harrison, M. J., Neufeld, A., \& Kushner, K. (1995). Women in transition: Access and barriers to social support. Journal of Advanced Nursing, 21, 858-864. http://dx.doi.org/10.1046/j.1365-2648.1995.21050858.x

Hill, E. J. (2005). Work-Family Facilitation and Conflict, Working Fathers and Mothers, Work-Family Stressors and Support. Journal of Family Issues, 26, 793-819. http://dx.doi.org/10.1177/0192513X05277542

Hinkin, T. R., \& Tracey, J. B. (2010). What makes it so great? An analysis of human resources practices among Fortune's best companies to work for. Cornell Hospitality Quarterly, 51, 158-228. http://dx.doi.org/10.1177/1938965510362487

Hyman, J., Scholarios, D., \& Baldry, C. (2005). Getting on or getting by? Employee flexibility and coping strategies for home and work. Work Employment Society, 19, 705. http://dx.doi.org/10.1177/0950017005058055

Idson, T. L., \& Feaster, D. J. (1990). A selectivity model of employer-size wage differentials. Journal of Labour Economics, 8, 99-122. http://dx.doi.org/10.1086/298238 
Johnson, J. T., Griffeth, R. W., \& Griffin, M. (2000). Factors discriminating functional and dysfunctional salesforce turnover. Journal of Business \& Industrial Marketing, 15, 399-415. http://dx.doi.org/10.1108/08858620010349493

Lapierre, L. M., Spector, P. E., Allen, T. D., Poelmans, S. A. Y., Cooper, C. L., O'Driscoll, M. P., Sanchez, J., Brough, P., \& Kinnunen, U. (2008). Family-Supportive Organization Perceptions, Multiple Dimensions of Work-Family Conflict, and Employee Satisfaction: A Test of a Model across Five Samples. Journal of Vocational Beavior, 73, 92-106. http://dx.doi.org/10.1016/j.jvb.2008.02.001

Lattice Group. (2010). Work-Life balance. The Lattice talks. Retrieved from http://www.nifi.org/stream_document.aspx?rID=10816\&catID=15\&itemID=10813\&typeID=8

Lewis, S., \& Smithson, J. (2001). Sense of entitlement to support for the reconciliation of employment and family life. Human Relations, 54, 1455-1481. http://dx.doi.org/10.1177/00187267015411003

Littig, B. (2008). Work Life Balance - catchword or catalyst for sustainable work? Retrieved from http://www.ihs.ac.at/publications/soc/rs85.pdf

Madsen, S. R. (2003). The effects of home-based teleworking on work-family conflict. Human Resource Development Quarterly, 14, 35-58. http://dx.doi.org/10.1002/hrdq.1049

Mano-Negrin, R., \& Tzafrir, S. S. (2004). Job search modes and turnover. Career Development International, 9 , 442-458. http://dx.doi.org/10.1108/13620430410550727

Maslach, C., Schaufeli, W. B., \& Leiter, M. P. (2001). Job burnout. Annual Review of Psychology, 52, 397-422. http://dx.doi.org/10.1146/annurev.psych.52.1.397

McMillan, H. S., Morris, M. L., \& Atchley, E. K. (2011). Constructs of the Work/Life interface: A Synthesis of the Literature and Introduction of the Concept of Work/Life Harmony. Human Resources Development Review, 10, 6-25. http://dx.doi.org/10.1177/1534484310384958

Moen, P., Kelly, E. L., \& Hill, R. (2011). Does enhancing work-time control and flexibility reduce turnover? A naturally occurring experiment. Social Problems, 58, 69-98. http://dx.doi.org/10.1525/sp.2011.58.1.69

Mosadeghrad, A. M. (2013). Quality of Working Life: An Antecedent to Employee Turnover Intention. International Journal of Health Policy and Management, 1, 43-50. http://dx.doi.org/10.15171/ijhpm.2013.07

Mudry, T., Kushner, K. E., \& Neufeld, A. (2010). Employed Mothers' Worker Ideology and Social Support Network Composition. Qualitative Health Research, 20, 905-921. http://dx.doi.org/10.1177/1049732310364221

Novozymes. (2010). Why work here? Our Benefits. Retrieved from http://www.novozymes.com/en/MainStructure/Careers/Why+Novozymes/Why+work+here.htm

OECD. (2008). Babies and Bosses: Balancing Work and Family Life. OECD Observer. Retrieved November 15, 2013 from http://www.oecd.org/dataoecd/12/2/34566853.pdf

Ongori, H. (2007). A review of the literature on employee turnover. African Journal of Business Management, $49-54$.

Parasuraman, S., \& Greenhaus, J. H. (2002). Toward reducing some critical gaps in work-family research. Human Resource Management Review, 12, 299-312. http://dx.doi.org/10.1016/S1053-4822(02)00062-1

Park, J. S., \& Kim, T. H. (2009). Do types of organizational culture matter in nurse job satisfaction and turnover intentions? Leadership in Health Services, 22, 20-38. http://dx.doi.org/10.1108/17511870910928001

Peus, C. (2006). Work-Family balance? The Case of Germany. Retrieved from http://web.mit.edu/workplacecenter/docs/wpc0025.pdf

Salzstein, A. L., Ting, Y., \& Salzstein, G. H. (2001). Work-family balance and job satisfaction. Public Administration Review, 61, 452-466. http://dx.doi.org/10.1111/0033-3352.00049

Schermerhorn, J. R., Hunt, J. G., \& Osborn, R. N. (2005). Organizational Behavior (9th ed.). New York: John Wiley \& Sons.

Somaya, D., \& Williamson, I. O. (2008). Rethinking the 'War for talent. MIT Sloan Management Review, 49, 29 34.

Stewart, M. J. (1993). Integrating social support in nursing. Newbury Park, CA: Sage. 
Swanberg, J., Werner, M., \& McKechnie, S. (2008). Workplace flexibility for hourly lower wage employees: A strategic business practice within one national retail firm. The Psychologist-Manager Journal, 11, 5-29. http://dx.doi.org/10.1080/10887150801963836

Švab, A. (2007). Combining Work and Family Life in Slovenia: An Ethic of care perspective for normative policy analysis. Društvena istraživanja, 16, 965-987.

Thévenon, O. (2008). Family policies in Europe: Available databases and initial comparisons. Vienna: Yearbook of Population Research 2008. http://dx.doi.org/10.1553/populationyearbook2008s165

Ton, Z., \& Huckman, R. S. (2008). Managing the Impact of Employee Turnover on Performance: The Role of Process Conformance. Organization Science, 19, 56-68. http://dx.doi.org/10.1287/orsc.1070.0294

Trefalt, S., \& Perlow, L. (2005). Learning from Women Who Make it Work. Qualitative Organizational Research, 227-252.

Valcour, M. (2007). Work-based resources as moderators of the relationship between work hours and satisfaction with work-family balance. Journal of Applied Psychology, 92, 1512-1523. http://dx.doi.org/10.1037/0021-9010.92.6.1512

Vanderpool1, C., \& Way, S. A. (2013). Investigating Work-Family Balance, Job Anxiety, and Turnover Intentions as Predictors of Health Care and Senior Services Customer-Contact Employee Voluntary Turnover. Cornell Hospitality Quarterly, 54, 149-160. http://dx.doi.org/10.1177/1938965513478682

Voydanoff, P. (2001). Conceptualizing Community in the Context of Work and Family. Community, Work and Family, 4, 133-189. http://dx.doi.org/10.1080/713658928

Woods, R. H. (1995). Managing Hospitality Human Resources. Educational Institute of the American Hotel and Motel Association, East Lansing, MI.

Zografos, G. (2006). Employee Turnover Statistics Remain a Great Tool. Franchising World, 38, 36-36.

\section{Appendix A}

Dendrogram resulting from cluster analysis (Euclidian distance; Ward method)

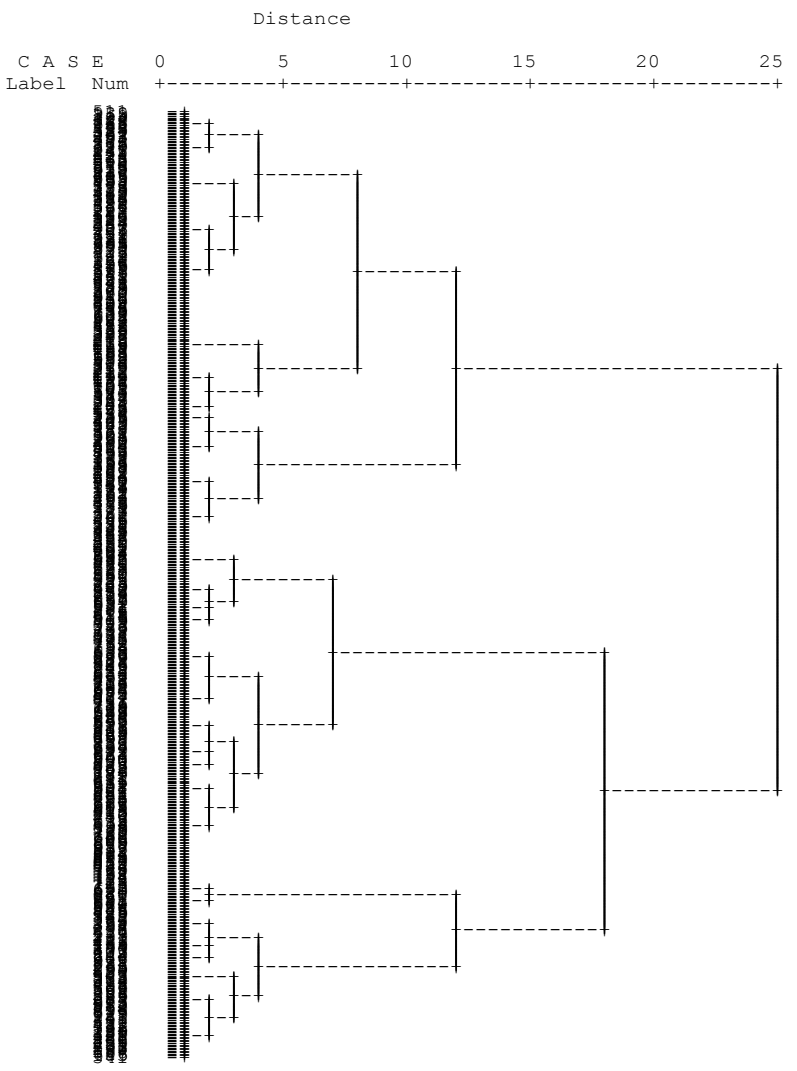




\section{Copyrights}

Copyright for this article is retained by the author(s), with first publication rights granted to the journal.

This is an open-access article distributed under the terms and conditions of the Creative Commons Attribution license (http://creativecommons.org/licenses/by/3.0/). 